\title{
The Effects of Factors in Modified UTAUT on Millennial Generation Customer Satisfaction
}

\author{
Agus Kurniawan ${ }^{1, *}$ Agus Rahayu ${ }^{2,}$ Lili Adi Wibowo ${ }^{3,}$ Heny Hendrayati ${ }^{4}$ \\ ${ }^{1}$ Universitas Pendidikan Indonesia \\ ${ }^{2}$ Universitas Pendidikan Indonesia \\ ${ }^{3}$ Universitas Pendidikan Indonesia \\ ${ }^{4}$ Universitas Pendidikan Indonesia \\ *Corresponding author. Email: akoer6@gmail.com
}

\begin{abstract}
Today's consumers are more thorough and selective before making a purchase. Today's consumer behavior is more "demanding " and quickly moved to other providers because they can easily make comparisons from the internet. Modified Unified Theory of Acceptance and Use of Technology (UTAUT) is the key to competing with other competitors. The purpose of this study is to determine the effect of perceived value on customer satisfaction. The results of this study together and support previous research in all studies found that Performance Expectancy (PE), Effort Expectancy (EE), Social Influence (SI), Facilitating Conditions (FC), and Behavioral Intention (BI) affect Customer Satisfaction. This type of research is causal using quantitative research. Empirical data was collected through a questionnaire given to the Bank BJB Branch Office users in Suci (BJB Digi) mobile banking service. This research uses SEM-Smart PLS analysis.
\end{abstract}

Keywords: UTAUT, customer satisfaction, performance expectancy, effort expectancy, social influence.

\section{INTRODUCTION}

The rapid development of technology is challenging financial service providers to provide extra ser-vices to their customers. The increasing penetration of cellular telephones has become a driving factor in shifting traditional banks' paradigm (with branches) to mobile banking. Technology has become an essential element in the design of the financial services industry. Innovation in telecommunications has ben-efited communications tools in the banking world. In 2006, a research entitled: Banking 2015, "Defining the future of banking," explained explicitly that in this era of global competition, the banking industry turned out to clients, and technology will be the main focus in developing the world banking sector.

The banking community answered the demand, such as Bank BJB as one of Indonesia's largest banks by launching the latest service, namely BJB Digi. In
September 2014, to improve the BJB Bank Mobile Banking service, the BJB Digi application was launched. This application is a banking service from BJB Bank for electronic transactions that are easier, faster, safer, and convenient by using a Smartphone. This application is a combination of other BJB Bank electronic banking services consisting of BJB SMS, BJB net, BJB info, and BJB ATM call. Table 1. Show $\mathrm{BPD}$ in the island of Java.

Table 1. BPD In The Island Of Java

\begin{tabular}{|c|c|c|c|c|c|}
\hline No & Bank & $\begin{array}{l}\text { Number of } \\
\text { Customers }\end{array}$ & $\begin{array}{c}\text { Net } \\
\text { profit }\end{array}$ & $\begin{array}{l}\text { Total } \\
\text { assets }\end{array}$ & $\begin{array}{c}\text { ATM } \\
\text { availability }\end{array}$ \\
\hline 1 & $\begin{array}{l}\text { Bank } \\
\text { BJB }\end{array}$ & 2.037 .199 & $\begin{array}{l}1,19 \\
\text { triliun }\end{array}$ & $\begin{array}{l}70,84 \\
\text { Triliun }\end{array}$ & 743 unit \\
\hline 2 & $\begin{array}{l}\text { Bank } \\
\text { DKI }\end{array}$ & 989.000 & $\begin{array}{l}339,00 \\
\mathrm{M}\end{array}$ & $\begin{array}{l}26,62 \\
\text { Triliun }\end{array}$ & 265 unit \\
\hline 3 & $\begin{array}{l}\text { Bank } \\
\text { DIY }\end{array}$ & 567.000 & $\begin{array}{l}140,36 \\
M\end{array}$ & $\begin{array}{l}5,6 \\
\text { Triliun }\end{array}$ & 51 unit \\
\hline 4 & $\begin{array}{l}\text { Bank } \\
\text { Jateng }\end{array}$ & 210.000 & $\begin{array}{l}765,66 \\
M\end{array}$ & $\begin{array}{l}30,9 \\
\text { Triliun }\end{array}$ & 67 unit \\
\hline
\end{tabular}




\begin{tabular}{|l|l|l|l|l|l|}
\hline 5 & $\begin{array}{l}\text { Bank } \\
\text { Jatim }\end{array}$ & 1.769 .342 & $724,63 \mathrm{M}$ & $\begin{array}{l}29,11 \\
\text { Triliun }\end{array}$ & 368 unit \\
\hline
\end{tabular}

The BJB Digi service's success can be seen from the responses or responses of customers who use this service. As researchers found in the Play Store application on smartphones about the ratings and comments of people who have downloaded the BJB Digi application, the BJB Digi application is good in the sense that this application has the advantage of being a pretty good application. The features inside are sufficient to accommodating daily transaction activities and facilitating services. Besides this BJB Digi application is very useful so that by using this application, the world feels in the grip under the demands of today's society. With the increasingly broad and diverse network of electronic banking services, customers can enjoy the convenience and conduct transactions with the Bank BJB. Besides, the development of features on each e-channel continues to be carried out in 2019, Bank BJB added several new features in the form of purchasing airplane tickets, train tickets, and payment of land and building tax (PBB). This is done to increase the number of transactions and add new customers to use the service.

Compared with other banks, BJB Digi services still have shortcomings. Although it is not significant yet, BJB services Net as a mobile service banking is the latest of BJB Bank also increased in terms of user registration. Customers who have registered for this service are 1, 420 increasing $24.23 \%$ with a frequency of 130. 882 transaction points of transactions that are most often done by customers using this service are balance information and mini statements.

In this study, the researchers chose the Bank BJB Branch Office in Suci Bandung because, for now, many people choose the bank to conduct all kinds of financial transactions. Thus, it needs to be analyzed to what extent customers are satisfied with mobile banking provided by the Bank BJB Branch Office in Suci Bandung.

Making consumers feel satisfied is the goal of every marketing, both satisfied with the services provided and satisfied with the use of the products we market. Satisfied consumers are precious to us as sellers because, with that satisfaction, consumers may return to buy products or use our services again in the future.

Traditionally, consumers' satisfaction or dissatisfaction is the difference between hope (expectation) and perception or perceived performance (perceived performance). Satisfaction is one of the goals of marketing. The purpose of marketing is to "fulfill and satisfy the needs and desires of target customers and be better than their rivals" [1]. Satisfaction will be formed if expectations and performance have the same high value. In realizing satisfaction with consumers, it is necessary to implement strategies that can trigger such satisfaction.

Bank BJB Branch Office in Suci must know what factors influence the acceptance or adoption of mobile banking technology (BJB Digi) to meet company and government targets. The correct theory/model approach to knowing this is the Unified Theory of Acceptance and Use of Technology (UTAUT) theory/model. The Unified Theory of Acceptance and Use of Technology (UTAUT) is appropriate to use because this theory/model is the latest technology acceptance theory/model that is a unification, synthesis, or summary of eight theories/models of technology acceptance that have ex-isted before. UTAUT has been widely used to re-search various types of technological innovations throughout the world, both organizational (continuous monitoring technology, clinical decision support, to TELKOM's TeNOSS information system), as well as consumer use (mobile shopping services, mobile internet, MRT I-Pass, to mobile banking). Based on reference, [2-6] factors or constructs in UTAUT which include Performance Expectancy (PE), Effort Expectancy (EE), Social Influence (SI), and Facilitating Condition (FC) affect Behavioral Intention (BI) with Age (Age), Gender (Gender), Experience (Experience), and Voluntariness of Use as variables that moderate the relationships between constructs.

Based on the description above, the adjudicator wants to conduct further research with the title "The Influence of Factors in Modified Unified Theory of Acceptance and Use of Technology (UTAUT) on Millennial Generation Customer Satisfaction to Adopt BJB Digi in Bank BJB Branch Office Suci in 2020.

\subsection{Customer satisfaction}

Satisfaction is one of the goals of marketing. This is supported by [1] opinion, which states that marketing aims to "meet and satisfy the needs and desires of target customers and be better than their rivals". Until now, there is no standard definition of customer satisfaction. However, some experts have tried to interpret the term customer satisfaction.

One way to determine a customer's satisfaction is the "survey method [1]. This can be done by submitting a statement related to the customer's possibility to make a repeat purchase, the customer's tendency to tell the goodness about the product he bought to others, and the customer does not complain or does not complain to the company. This is based on reference [1] explanation, which states that satisfied customers will most likely repurchase the product and tend to share the goodness about the product they bought with others. Dissatisfied customers will likely discard or return the product they have bought and complain to the company. 
The satisfaction indicator in this study refers to reference [1], which is "customers make repeat purchases, customers tell the best about the products they buy to others, customers do not complain or do not complain to the company".

\subsection{Theory of acceptance and use of technology (UTAUT)}

According to reference [7] in [8], UTAUT is a definitive model that synthesizes what is known. By including the explanatory power of individual models and considering the main effects of moderation. The Unified Theory of Acceptance and Use of Technology (UTAUT) 's core constructs include performance expectancy, effort expectancy, social influence, and facilitating conditions.

Factors that directly influence behavioral intention in adopting information technology are performance expectancy, effort expectancy, social influence, facilitating conditions. These four variables have been proven to have a direct effect on behavioral intention, and behavioral intention influences the use of behavior in the adoption of systems and information technology in various studies such as in $[5,9,10,3,4]$. (1) Performance Expectancy is the level where technology will pro-vide benefits for consumers in carrying out an activity. Performance expectancy or performance expectations are positively and significantly related to behavioral intention to adopt the technology. (2) Effort Expectancy expectation is the level of ease associated with the use of consumers in technology. Ekspekstasi effort (effort expectancy) is a positive and significant effect on behavioral intention technology adoption. (3) Social influence is the level at which a consumer perceives that others who are important to him, such as family and friends, believe that he should use certain technologies. social influence has a positive and significant relationship to the adoption of technology or system decisions. (4) Facilitating Conditions is the perception of the availability of support and resources to perform a behavior. Conditions that facilitate (Facilitating Conditions) have a relationship and a positive and significant effect on the behavior intention and actual use behavior in adopting the technology or system. (5) Behavioral intention is the readiness, desire, or the possibility of subjective someone to perform a specific behavior.

\subsection{Conceptual framework and hypotheses}

Based on the theory and conceptual framework previously stated, the hypothesis can be developed by Fig. 1.

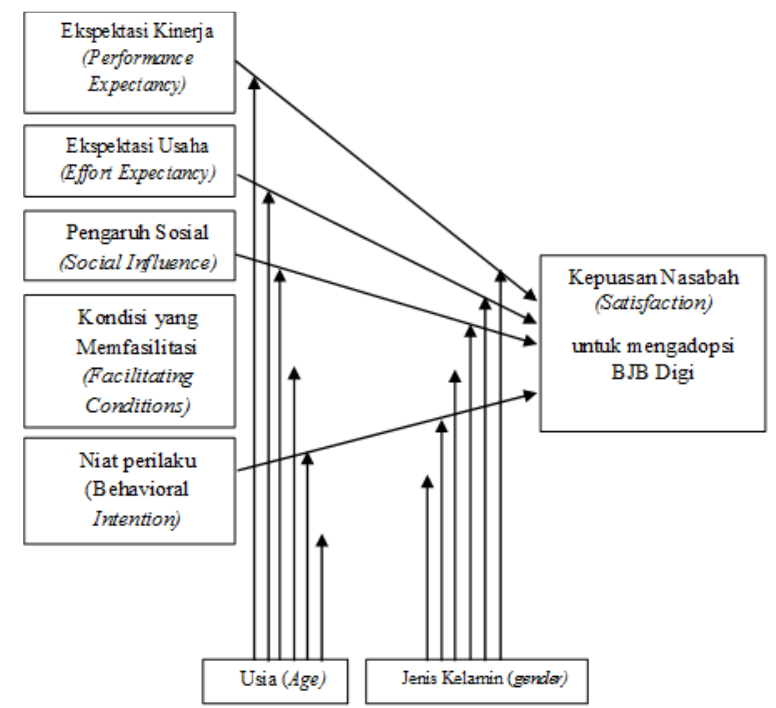

Figure 1. Conceptual framework

H1: Performance expectancy has a positive influence on customer satisfaction

H2: Effort expectancy has a positive influence on customer satisfaction

H3: Social influence has a positive influence on customer satisfaction

H4: Facilitating conditions have a positive influence on customer satisfaction

H5: Behavioral intention have a positive influence on customer satisfaction

H6: Dimensions of UTAUT simultaneously have a positive influence on customer satisfaction

\section{METHODS}

This research is quantitative to analyze the relationship between business intelligence, innovation, network learning, and startup performance. The unit of analysis used is customers of the Bank BJB Branch Office in Suci Bandung, totaling 100 people. Sampling is done by the total sampling technique, meaning that all populations are sampled in this study.

The data obtained were then analyzed using PLS analysis, given the small sample size. The analysis in this study uses SmartPLS 3.0 software.

\section{RESULT AND DISCUSSION}

\subsection{RESULT}

\subsubsection{Assessment of measurement models}

After an analysis using SmartPLS, we found that some indicators had an outer loading value of less than 0.7 so that the indicators were removed, and the model 
was retested. After retesting, it was found that all indicators have an outer loading value of more than 0.7 , so that further analysis is performed.

Internal reliability was analyzed using the composite reliability reference, and values obtained from all variables were more than 0.6 so that all variables were stated to be reliable.

Discriminant validity was evaluated using crossloading values (for indicator levels) and Fornell-Larcker Criteria (for variable levels). The results obtained for cross-loading and AVE values meet the criteria so that all variables are declared valid.

\subsubsection{Assessment structural models}

The coefficient of determination of the model can be seen from adjusted R2 showing that the percentage of the influence of relationship marketing on customer satisfaction of $57.4 \%$. Table 2. Show determinant coefficient.

Table 2. Determinant Coefficient

\begin{tabular}{|l|l|}
\hline \multicolumn{1}{|c|}{ Variable } & \multicolumn{1}{c|}{ R-square } \\
\hline Performance Expectancy & - \\
\hline Effort Expectancy & - \\
\hline Social Influence & - \\
\hline Facilitating Condition & - \\
\hline Behavioral Intention & - \\
\hline Customer satisfaction & 0.574 \\
\hline
\end{tabular}

To test the hypothesis analyzed using the rule of thumb, viz (1) if the coefficient or direction of the variable relationship (indicated by the original sample value) matches what was hypothesized, and (2) if the statistical t-value is greater than 1.703 (one-tailed) and (3) the probability value (p-value) is less than $5 \%$. The results of testing the complete hypothesis can be seen in the following table 3 .

Table 3. Hypotheses Test Result

\begin{tabular}{|l|l|l|}
\hline \multicolumn{1}{|c|}{ Variable } & \multicolumn{1}{|c|}{$\begin{array}{c}\text { Path } \\
\text { coeffiecient }\end{array}$} & \multicolumn{1}{|c|}{$\begin{array}{c}\text { Descriptio } \\
\text { n }\end{array}$} \\
\hline $\begin{array}{l}\text { Performance Expectancy -> } \\
\text { Customer satisfaction }\end{array}$ & 0.020 & Accepted \\
\hline $\begin{array}{l}\text { Effort Expectancy -> Customer } \\
\text { satisfaction }\end{array}$ & 0.101 & Accepted \\
\hline $\begin{array}{l}\text { Social Influence -> Customer } \\
\text { satisfaction }\end{array}$ & 0.164 & Accepted \\
\hline $\begin{array}{l}\text { Facilitating Condition -> } \\
\text { Customer satisfaction }\end{array}$ & 0.199 & Accepted \\
\hline $\begin{array}{l}\text { Behavioral Intention -> Customer } \\
\text { satisfaction }\end{array}$ & 0.397 & Accepted \\
\hline
\end{tabular}

\section{CONCLUSION}

Based on the path coefficient analysis with a probability value (p-value) of less than 0.05 or $5 \%$. This means that Ho was refused. Ha accepted. Therefore, it can be concluded that there is a significant influ-ence between Unified Theory of Acceptance and Use of Technology (UTAUT) on Bank BJB Branch Office's customer satisfaction in Suci Bandung. In other words, better web design at Bank Jabar Banten further improves marketing relationships, in this case, with the customers of Bank BJB Branch Office in Suci Bandung. Conversely, if the Unified Theory of Acceptance and Use of Technology (UTAUT) gets worse, the satisfaction of customers Bank BJB Branch Office in Suci Bandung will decrease.

\section{ACKNOWLEDGMENT}

We would like to express our gratitude to Universitas Pendidikan Indonesia, which has facilitated the research to its completion.

\section{REFERENCES}

[1] P. Kotler, and K.L. Keller, Marketing Management, 14th Ed. Pearson Education, 2012.

[2] M.A. Almaiah, M.M. Alamri, and W. Al-Rahmi, "Applying the UTAUT model to explain the students' acceptance of mobile learning system in higher education," IEEE Access, pp. 1-1, 2019.

[3] C.S. Yu, "Factors affecting individuals to adopt mobile banking: Empirical evidence from the utaut model," J. Electron. Commer. Res., 2012.

[4] Y. Sok Foon and B. Chan Yin Fah, "Internet banking adoption in Kuala Lumpur: An application of UTAUT model,” Int. J. Bus. Manag., 2011.

[5] G.C. Gonzalez, P.N. Sharma, and D.F. Galletta, "The antecedents of the use of continuous auditing in the internal auditing context," Int. J. Account. Inf. Syst., 2012.

[6] Indrawati and D. A. Putri, "Analyzing factors influencing continuance intention of E-payment adoption using modified UTAUT 2 Model: (A case study of Go-Pay from Indonesia)," in 2018 6th International Conference on Information and Communication Technology, ICoICT 2018, 2018.

[7] V. Venkatesh, M.G. Morris, G.B. Davis, and F.D. Davis, "User acceptance of information technology: Toward a unified view," MIS Q. Manag. Inf. Syst., 2003.

[8] M. Hamidfar, M. Limayem, and S.H. Zegordi, "using the UTAUT model to explore Iranian physicians and nurses' intention to adopt electronic patient records," in Proceedings of the 2008 International Conference on e-Learning, eBusiness, Enterprise Information Systems, and eGovernment, EEE 2008, 2008.

[9] Z. Wang and N. Wang, "Knowledge sharing, innovation and firm performance," Expert Syst. Appl., vol. 39, no. 10, pp. 8899-8908, 2012, doi: 10.1016/j.eswa.2012.02.017.

[10] W. Shu and Y. H. Chuang, "The perceived benefits of six-degree-separation social networks," Internet Res., 2011. 